\title{
Long-term impact of protected colonial birds on a jeopardized cork oak population: conservation bias leads to restoration failure
}

\author{
José M. Fedriani ${ }^{1,2 *}$, Luis V. García ${ }^{3}$, María E. Sánchez ${ }^{4}$, Juan Calderón ${ }^{1}$ and \\ Cristina Ramo ${ }^{1}$ \\ ${ }^{1}$ Estación Biológica de Doñana (EBD-CSIC), c/Américo Vespucio s/n, 41092 Seville, Spain; ${ }^{2}$ Centre for Applied \\ Ecology 'Prof. Baeta Neves'/InBIO, Institute Superior of Agronomy, University of Lisbon, Tapada da Ajuda, 1349-017 \\ Lisboa, Portugal; ' Instituto de Recursos Naturales y Agrobiología de Sevilla (IRNAS-CSIC), P. O. Box 1052, 41080 \\ Seville, Spain; and ${ }^{4}$ Agronomy Department (Agroforest Pathology), University of Córdoba, Ctra. Madrid-Cádiz Km \\ 396, 14014 Córdoba, Spain
}

\begin{abstract}
Summary
1. Conservation bias towards flagship species sometimes threatens other species of chief concern. Long-term studies of potential harm by favoured species on other sensitive species, though seldom adopted, are required to fairly evaluate the suitability of management and restoration efforts.

2. We illustrate the potential detrimental outcomes of conservation biased towards birds by investigating the long-term (1963-2009) impact of a large waterbird colony (up to 13000 pairs) on a remnant cork oak Quercus suber population at a World Biosphere Reserve in south-western Spain (the Doñana National Park). To this end, we compared changes in performance (growth, crown vigour and survival) of oaks occupied and unoccupied by the waterbird colony.

3. After 46 years of occupation, the risk of death to centenarian oaks in the area occupied by the colony was over twofold higher than for trees outside the area. Non-centenarian planted and naturally regenerated oaks showed similar trends, leading to restoration failure.

4. Synthesis and applications. Our long-term study reveals that waterbirds and centenarian oaks cannot coexist, at the most local scale, but they can at a regional scale including within the Doñana area. We propose immediate planting efforts in suitable colony-free areas, while managers evaluate the feasibility of relocating colonial waterbirds to an alternative location. To preserve the Doñana oak genetic pool, such reforestation should be accomplished using local seeds and seedlings. New trees should not be planted in close proximity of colony-occupied trees since it significantly reduces their survival. Doñana stakeholders should both overcome current conservation bias in favour of birds and enter into a process of settlement to best preserve the overall biodiversity of the system.
\end{abstract}

Key-words: conservation bias towards waterbirds, conservation conflicts, Doñana National Park, ecological restoration, genetic pool, long-term monitoring, Mediterranean ecosystem, plant-animal interactions, Quercus suber, tree mortality

\section{Introduction}

Conservation action is prone to bias due to habitats or ecosystems (e.g. Pressey et al. 2002; Mokhatla et al. 2012), species' economic importance, threat status, size or emotional appeal (Ceballos and Brown 1995; Simberloff

*Correspondence author. E-mail: fedriani@ebd.csic.es
1998; Root-Bernstein et al. 2013). Conservation biased towards flagship species (Simberloff 1998) may threaten other species of concern and, thus, generate divergences among conservationists with contrasting sensitivity or priorities (Oro et al. 2009; Redpath et al. 2013; McAlpine et al. 2016). Importantly, even moderate yet temporally persistent habitat alterations by favoured species could eventually harm other coexisting species (Tilman et al. 1994; Gustavsson, Lennartsson \& Emanuelsson 2007). 
Especially paradoxical are those situations in which flagship species compromise their own local persistence by reducing or even decimating the long-term survival of other populations upon which they rely (Roemer \& Wayne 2003; Redpath et al. 2013). Long-term studies of potential harm by favoured species on other sensitive species, though seldom adopted, are required to fairly evaluate the suitability of conservation efforts.

Birds are often prioritized in conservation and restoration programmes because they are considered charismatic species and also provide critical ecosystem services (Whelan, Wenny \& Marquis 2008; Verissimo, MacMillan \& Smith 2011; Green \& Elmberg 2014). Nonetheless, tree damage due to the persistent nesting of colonial waterbirds has been reported world-wide (e.g. Telfair \& Bister 2004; Kolb et al. 2012). Bird detrimental effects include direct damage by breaking branches and foliage for nest construction or by covering leaves with faeces (Aderman \& Hill 1995; Ishida 1997) as well as indirect harm by changing soil composition through deposition of large amounts of guano (e.g. Breuning-Madsen et al. 2010; García et al. 2011; but see Fedriani et al. 2015a). Large scattered trees are keystone elements in savannah-like ecosystems because their large cavities and complex canopy structure provide vital shelter and other benefits to numerous animal species (Fischer, Stott \& Law 2010; Díaz, Tietje \& Barrett 2013; Lindenmayer et al. 2013). In these ecosystems, birds can limit tree survival and recruitment and thus jeopardize these keystone tree species, especially when they act in combination with other detrimental factors (e.g. logging, overgrazing, droughts).

In a Mediterranean area of southern Spain, Doñana Biological Reserve (DBR), only a few scattered stands of formerly abundant cork oaks Quercus suber currently persist mostly due to a history of human-related disturbances (e.g. timber exploitation, fires; Granados, Martín \& García-Novo 1988). In 1967, Doñana was declared a National Park, mostly because of its importance as a European bird reserve (García-Novo \& Marín-Cabrera 2005; Martín-López et al. 2009). Since then, several factors such as the decline of human disturbances and the availability of novel food resources (e.g. the invasive crayfish Procambarus clarkii, creation of fish-farming ponds) have enabled a remarkable increase in several nationally protected tree-nesting waterbirds (Tablado et al. 2010; del Estado 2011; Ramo et al. 2013). This enhanced waterbird guild rapidly colonized a large fraction of the remaining centenarian cork oaks in the most productive area of DBR (Ramo et al. 2013). The large amount of faeces delivered by the waterbird colony (up to 13000 pairs) altered soil composition and led to a decline in the health of the oak crowns (García et al. 2011). To offset those and other detrimental effects on centenarian oaks (droughts, herbivory; Herrera 1995), several costly oak reforestation campaigns have been undertaken during the last few decades with limited success. Surprisingly, despite such a palpable 'birds vs. oaks' conservation conflict, and despite the pressing need for well-informed restoration programmes, whether and how the waterbird colony has impinged on the long-term performance and survival of both naturally regenerated and planted oaks remains unknown.

In this study, we investigated the potential impacts of a large waterbird colony on a charismatic remnant population of cork oaks at Doñana World Biosphere Reserve for five decades. We hypothesized that such a large waterbird colony would have detrimental long-term effects on critical individual oak performance components such as growth, crown vigour and survival. Our analysis considered two distinct tree age classes (centenarian and noncentenarian oaks; hereafter referred to as $\mathrm{CO}$ and NCO, respectively) and sought to answer the following four specific questions: (i) Have tree-nesting waterbirds altered growth, crown vigour and survival of Doñana CO? (ii) Does the proximity of colony-occupied conspecifics harm the survival of CO? (iii) Is the impact of nesting waterbirds on NCO similar to their impact on CO? and (iv) Are colony effects similar on planted and naturally regenerated $\mathrm{NCO}$ ?

\section{Materials and methods}

\section{STUDY AREA AND SPECIES}

The study was conducted at the DBR (6794 ha) in the heart of the Doñana National Park (south-west Spain). The climate is Mediterranean with some Atlantic influences. Average annual rainfall is $586 \mathrm{~mm}$, with $84 \%$ occurring in autumn and winter, while average monthly temperatures range from $10 \cdot 0^{\circ} \mathrm{C}$ (January) to $24.7^{\circ} \mathrm{C}$ (July). The DBR has three main ecosystems: mobile dunes, stabilized sands and marshes (Fig. 1). Oaks tend to occupy low-lying locations with relatively moist soils and form sparse and open savannah-like woodland (García-Novo 1979).

The cork oak is an evergreen species of remarkable ecological and economic importance, endemic to the Mediterranean region (Aronson, Pereira \& Pausas 2009). It has low tolerance to cold temperatures (frost) and severe droughts and tends to grow in acidic soils (Aronson, Pereira \& Pausas 2009). Changes in land use and forest management (Aronson, Pereira \& Pausas 2009) and the presence of invasive soil-borne pathogens (Phytophthora cinnamomi and Pythium spiculum; Gómez-Aparicio et al. 2012) led to a significant decline in these forests, which are now considered endangered (Aronson, Pereira \& Pausas 2009) and highly vulnerable to forecasted climate change (Felicísimo et al. 2011).

Since its establishment in 1963, the wading bird colony has moved along a strip ( $\sim 365$ ha) occupying oaks and other tree species (Populus alba, Salix sp., and Olea europaea) within the DBR. This highly productive area, locally known as 'Vera' (Fig. 1), corresponds to the scrubland-marshland ecotone. Today the colony consists of seven nationally protected waterbird species (del Estado 2011): black-crowned night heron Nycticorax nycticorax, squacco heron Ardeola ralloides, cattle egret Bubulcus ibis, little egret Egretta garzetta, grey heron Ardea cinerea, white stork Ciconia ciconia and spoonbill Platalea leucorodia. The colony size varies yearly from 150 to 13000 breeding pairs (Ramo et al. 2013). 


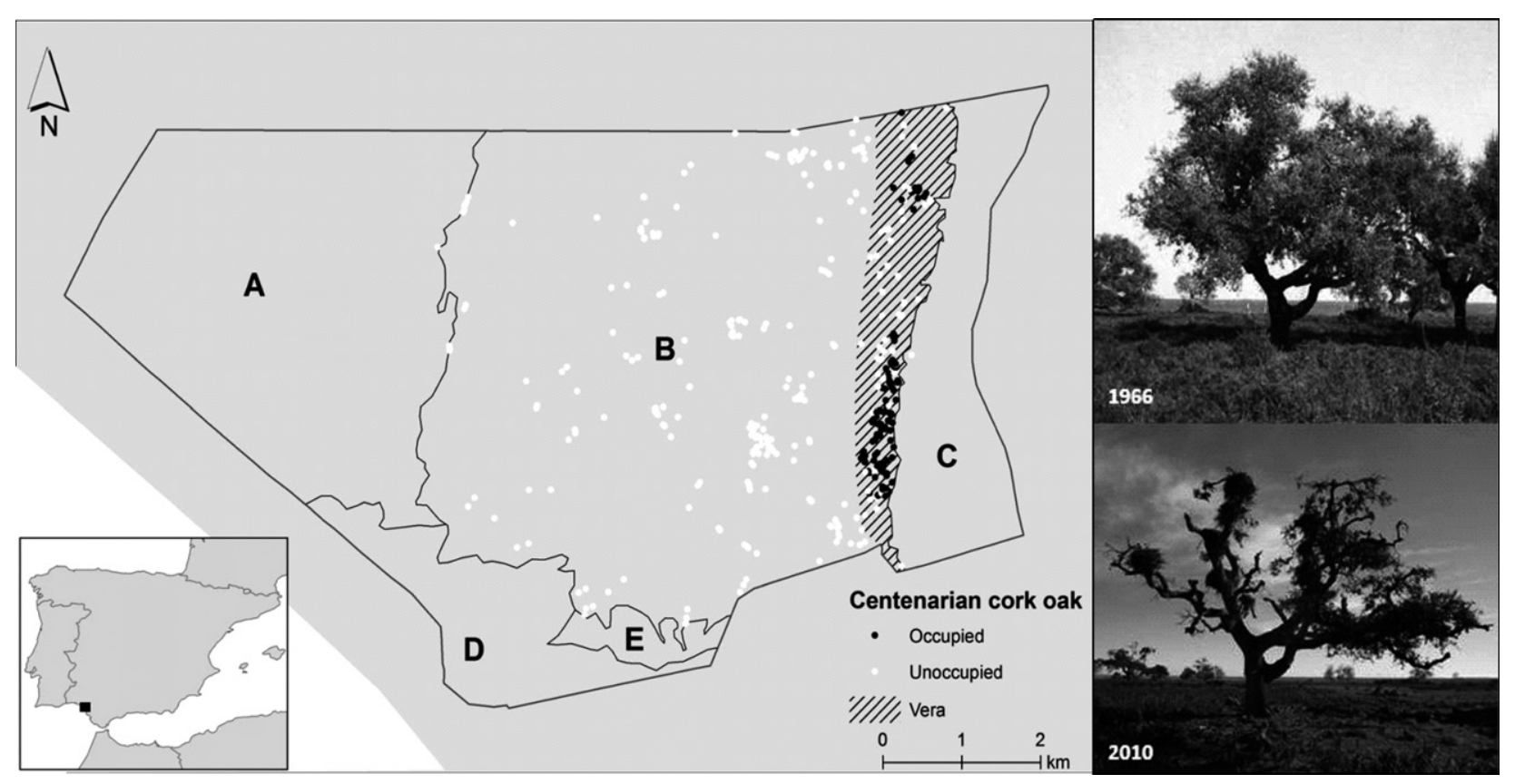

Fig. 1. Main habitat types in the Doñana Biological Reserve (south-west Spain) and location of the centenarian cork oaks (CO). Solid dots represent CO occupied by the colony at any time during the period 1963-2010, while white dots represent unoccupied CO. Dashed lines indicate the scrubland-marshland ecotone locally known as 'Vera'. (a) Stabilized sands (elevated ground); (b) stabilized sands (low ground); (c) marshes; (d) mobile dunes; (e) freshwater ponds. On the right are examples of photographs taken to assess changes in oak crown condition.

\section{WATERBIRD COLONY EFFECTS ON GROWTH, CROWN CONDITION AND SURVIVAL OF CENTENARIAN OAKS}

In 1963, most of the existing CO in the DBR $(n=454)$ were marked and numbered. In subsequent years $(1981,1989,1992$, 1996 and 2009), surveys were carried out registering the number of surviving trees both within and outside the Vera (Solís 1996). To evaluate whether the colony had an effect on $\mathrm{CO}$ crown condition (e.g. Carnicer et al. 2011), we compared photographs of 136 CO (occupied, $n=72$; unoccupied $n=64$ ) taken from around the same camera positions in 1966 and 2010 (see Fig. 1). The tree crown condition of photographed oaks was visually estimated using an index of crown vigour (ICV). It consists of an ordinal index that rises as crown conditions improve, and ranges between 1 (alive tree in very poor condition) and 5 (very healthy reference tree; García et al. 2011). For analysis, we rescaled the index from 20 (alive tree in very poor condition) to $100 \%$ (very healthy tree). Tree occupancy by the colony was based on data from the annual nest census performed by the DBR Monitoring Team (period 1985-2010), the presence of recent and old nests, and valuable guard communications. For occupied trees, we also evaluated whether their mean ICV values (averaged for the last 3 years of monitoring) were related to intensity of occupation, measured as: (i) the number of years each tree was occupied during a 25-year monitored period (1985-2009) and (ii) the accumulated number of nests during a 17-year monitored period (19932009). Similarly, to evaluate the long-term potential colony effect on oak growth, the circumference at breast height of a subset of 120 trees was measured both in 1966 and 2010 (occupied, $n=75$; unoccupied, $n=45$ ). For analyses, the standard diameter at breast height (d.b.h.) was estimated assuming circular trunk section (Nogueira, Nelson \& Fearnside 2006).

\section{WATERBIRD COLONY EFFECTS ON CROWN CONDITION AND SURVIVAL OF NON-CENTENARIAN OAKS}

To assess the potential colony effect on oak reforestation programmes within the Vera, we initiated in 2008 a detailed monitoring of NCO that were either planted before $2005(n=256)$ or naturally recruited $(n=56)$. Because the smallest size (d.b.h.) of occupied NCO (i.e. trees that could potentially be occupied by the colony) was $13 \mathrm{~cm}$, only trees above that size were considered. During the autumns of seven consecutive years (2008-2014), we assessed in the field the crown vigour (ICV) and the status (alive/ dead) of each focal tree.

\section{STATISTICAL ANALYSIS}

To evaluate potential colony effects on $\mathrm{CO}$ crown vigour (ICV) and growth (d.b.h.), we fit generalized linear mixed models using Proc Glimmix in SAS (Littell et al. 2006). Centenarian oaks were categorized within three types according to location and colony occupancy: trees occupied and unoccupied in Vera and trees in the scrubland (all unoccupied). Tree type, year (1966 and 2009) and their second-order interaction were specified in the models as fixed factors. Individual tree (i.e. block) was included as a random factor. Arcsine-transformed ICV data, normal error and identity link function were used in the models (Bolker et al. 2009). When the interaction between tree type and year was significant, we performed tests for the effect of a given factor at the different levels of the other factor using the SLICE option in the LSMEANS statement of the MIXED procedure (Littell et al. 2006). Also, for colony-occupied trees, we evaluated a potential long-term relationship between the intensity of tree occupation (as defined above) and the average ICV (last 3 years) by means of simple regression. 
Waterbird colony effect on CO survivorship was first evaluated by means of failure-time analyses, fitting Cox proportional hazard regression models (e.g. Fedriani, Zywiec \& Delibes 2012). The response variable was the number of years between the start of monitoring in 1963 and oak death (or end of monitoring), whereas tree type (as defined above) was the explicative variable. Data were modelled as right-censored given the uncertainty about when CO alive at the study end (2009) will eventually die. The significance of tree type was evaluated following Therneau \& Grambsch (2000). We also hypothesize that dead CO in the Vera would be surrounded by a higher number of occupied conspecifics than expected given the mean number neighbouring occupied oaks. To address this question, we used recent techniques of marked spatial point pattern analysis (e.g. Fedriani et al. 2015b; see Appendix S1, Supporting information for details).

Potential colony effects on non-centenarian planted and naturally regenerated oaks within the Vera were evaluated as above. Generalized linear mixed models (Littell et al. 2006) were used to evaluate the effect of tree type (either occupied or not by the colony; all within Vera), tree origin (planted or naturally regenerated) as well as their second-order interaction on mean ICV (averaged across 2008-2014). For colony-occupied NCO, we also evaluated the potential relationship between the intensity of colony occupation and their mean ICV using simple regression. Finally, Cox proportional hazard regression models were used to assess the effect of tree type, tree origin and their second-order interaction on NCO survivorship. All other procedures and conventions were as detailed above.

\section{Results}

\section{LONG-TERM WATERBIRD COLONY EFFECTS ON} CENTENARIAN OAKS

Size of CO (d.b.h.) was variable both within Vera $[73 \cdot 14 \pm 2 \cdot 08$ (mean $\pm 1 \mathrm{SE})$; range, 24.19-151.13, $n=178]$ and within scrubland (78.85 \pm 4.58 ; range, 19.10-153.42; $n=62$ ). When we controlled for the effect of the random factor (i.e. individual tree), our mixed model showed no effect of tree type on oak d.b.h. $\left(F_{1,117}=1 \cdot 49, P=0 \cdot 231\right)$. However, there was a marked effect of year (1966 and 2010) on d.b.h. $\left(F_{1,117}=586.85, P<0.0001\right.$; Fig. 2$)$; as would be expected since they were 44 years older, $\mathrm{CO}$ in 2010 were on average wider $(\sim 1 \cdot 5$-fold $)$ than in 1966 . Interestingly, we found a significant interaction between tree type and year $\left(F_{2,117}=6.79, P<0.002\right)$, indicating temporal change in d.b.h. among tree types. Specifically, tests of slices showed that although there were no differences among tree types at the start of the monitoring in $1966 \quad\left(F_{2,117}=0 \cdot 38\right.$, $P=0.682$ ), by 2010 the diameter of occupied oaks was on average $14 \%$ smaller than unoccupied trees both within and outside Vera $\left(F_{2,117}=3 \cdot 22, P=0 \cdot 044\right.$; Fig. 2).

Index of crown vigour (ICV) for $\mathrm{CO}$ was most variable between years $[86.89 \pm 0.013$ (1966) vs. $90.45 \pm 0.013$ (2010)]. Indeed, our mixed model showed that average ICV was significantly higher in 2010 than in $1966\left(F_{1,133}=4.41\right.$, $P=0.037$; Fig. 3a). Though tree type did not have an effect as main factor $\left(F_{2,133}=1 \cdot 29, P=0.278\right)$, it showed a significant interaction with year $\left(F_{2,133}=3.59, \quad P<0.030\right)$

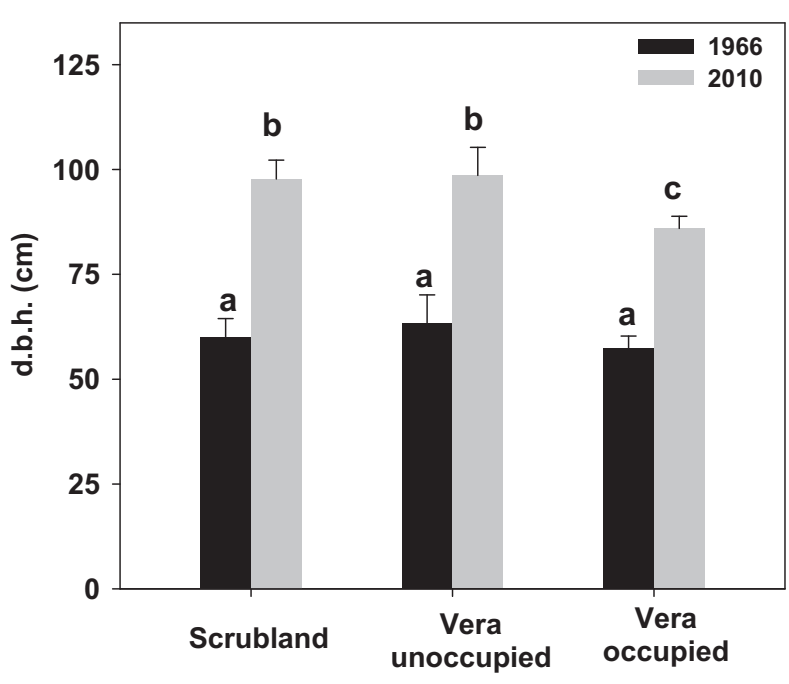

Fig. 2. Model-adjusted mean diameter (d.b.h.; $\pm 1 \mathrm{SE}$ ) during 1966 and 2010 of CO occupied and unoccupied by nesting waterbirds in the area used (Vera) and not used (Scrubland) by the colony. Different letters denote significant differences.

indicating that the effect of tree type was temporally inconsistent. Specifically, tests of slices indicated that whereas in 1966 there were no differences in ICV between occupied and unoccupied trees $\left(F_{2,133}=0 \cdot 18, P=0.837\right)$, during 2010 unoccupied trees (both outside and inside Vera) showed on average ICV $7-9 \%$ higher than occupied trees $\left(F_{2,133}=4 \cdot 24, P=0.016\right.$; Fig. 3a). Furthermore, for colony-occupied trees, there was a weak though significant negative linear trend between the number of years occupied by the colony and ICV $\left(r=-0.223, P=0.033 ; R^{2}=0.050\right.$; Fig. 4a). No relationship across CO between average ICV and the accumulated number of nests during the monitored period was detected $(P=0 \cdot 344)$.

Finally, Cox regression analysis indicated that survival differed among $\mathrm{CO}$ inside and outside the Vera $\left(\chi^{2}=19 \cdot 22\right.$, d.f. $\left.=1, P<0 \cdot 0001\right)$. Specifically, risk of oak death during the 46-year monitored period was $2 \cdot 1$ times higher in the Vera than in the scrubland (Fig. 5a). Also, marked spatial point pattern analyses revealed that the number of colony-occupied conspecific neighbours around dead oaks was always much higher than expected by the random marking model (see Appendix S1).

\section{WATERBIRD COLONY EFFECT ON NON-CENTENARIAN} OAKS

During the 7-year period examined (2008-2014), a much larger fraction of planted oaks $(29.7 \%, n=256)$ was occupied by the colony as compared to naturally regenerated ones $(8.9 \%, n=56)$. Mean ICV values for NCO were variable for both planted $(0.58 \pm 0.01$; range, $0 \cdot 27$ $0.91 ; n=256)$ and naturally regenerated individuals $(0.57 \pm 0.01 ;$ range, $0 \cdot 36-0 \cdot 80 ; n=56)$. Average ICV did not vary between planted and naturally regenerated trees $\left(F_{1,308}=0.68, P=0.410\right.$; Fig. 3 b). However, there was a significant colony effect $\left(F_{1,308}=14.06, P<0.001\right)$ with 
(a) Centenarian oaks

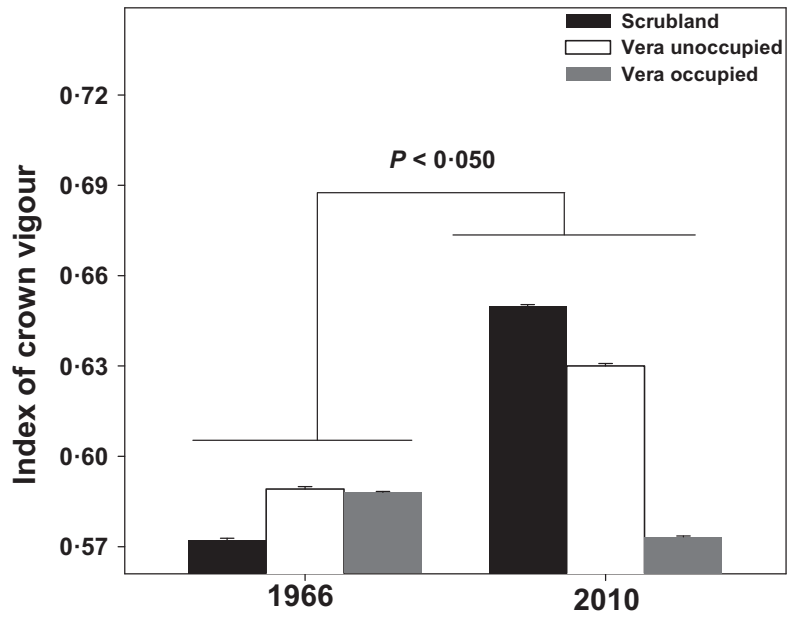

(b) Non-centenarian oaks

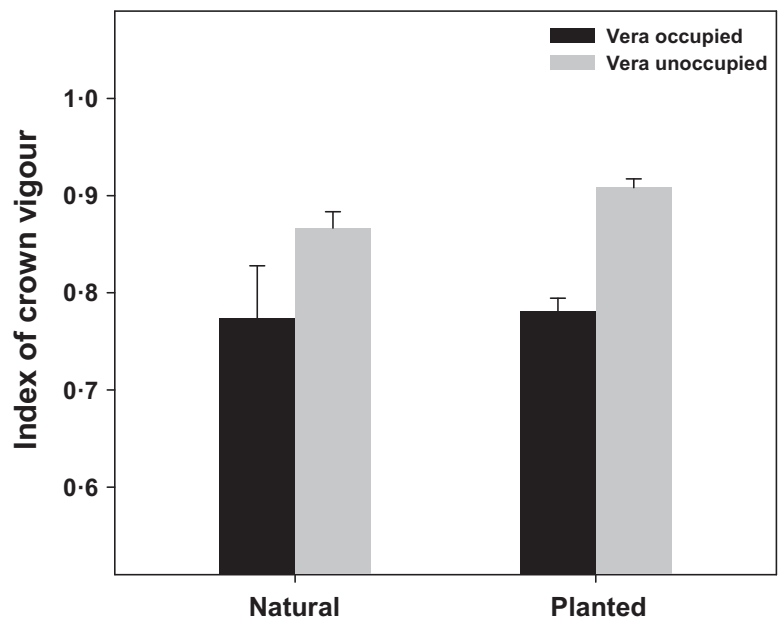

Fig. 3. (a) Model-adjusted mean ( $\pm 1 \mathrm{SE}$ ) index of crown vigour (ICV) during 1966 and 2010 of CO occupied and unoccupied by the nesting waterbirds in the area used (Vera) and not used (Scrubland) by the colony. (b) Model-adjusted mean ICV [average across a 7-year period (2008-2014)] of NCO occupied and unoccupied by the nesting waterbirds in the Vera. Differences were significant $(P<0.001)$ for both planted and naturally regenerated trees.

unoccupied trees having on average a $22 \%$ higher ICV than occupied ones. There was no significant interaction between tree origin and colony occupancy $\left(F_{1,308}=0 \cdot 36\right.$, $P=0.550)$. When considering only NCO occupied by the colony $(n=81)$, average ICV showed a strong negative relationship with both the number of years trees were occupied by the colony $(r=-0.490, \quad P<0.0001$, $R^{2}=0.2402$; Fig. $\left.4 \mathrm{~b}\right)$ and the accumulated number of nests $\left(r=-0 \cdot 310, P<0.005, R^{2}=0.096\right.$; Fig. 4c).

Survivorship of NCO clearly differed between occupied and unoccupied ones (Cox regression, $\chi^{2}=11 \cdot 16$, d.f. 1 , $P<0.001)$. Risk of death across the 7-year monitored period was 6.7 times higher for occupied than for unoccupied oaks (Fig. 5b). This trend was consistent for both planted and naturally regenerated oaks, as indicated by the lack of significant interaction between colony (a)
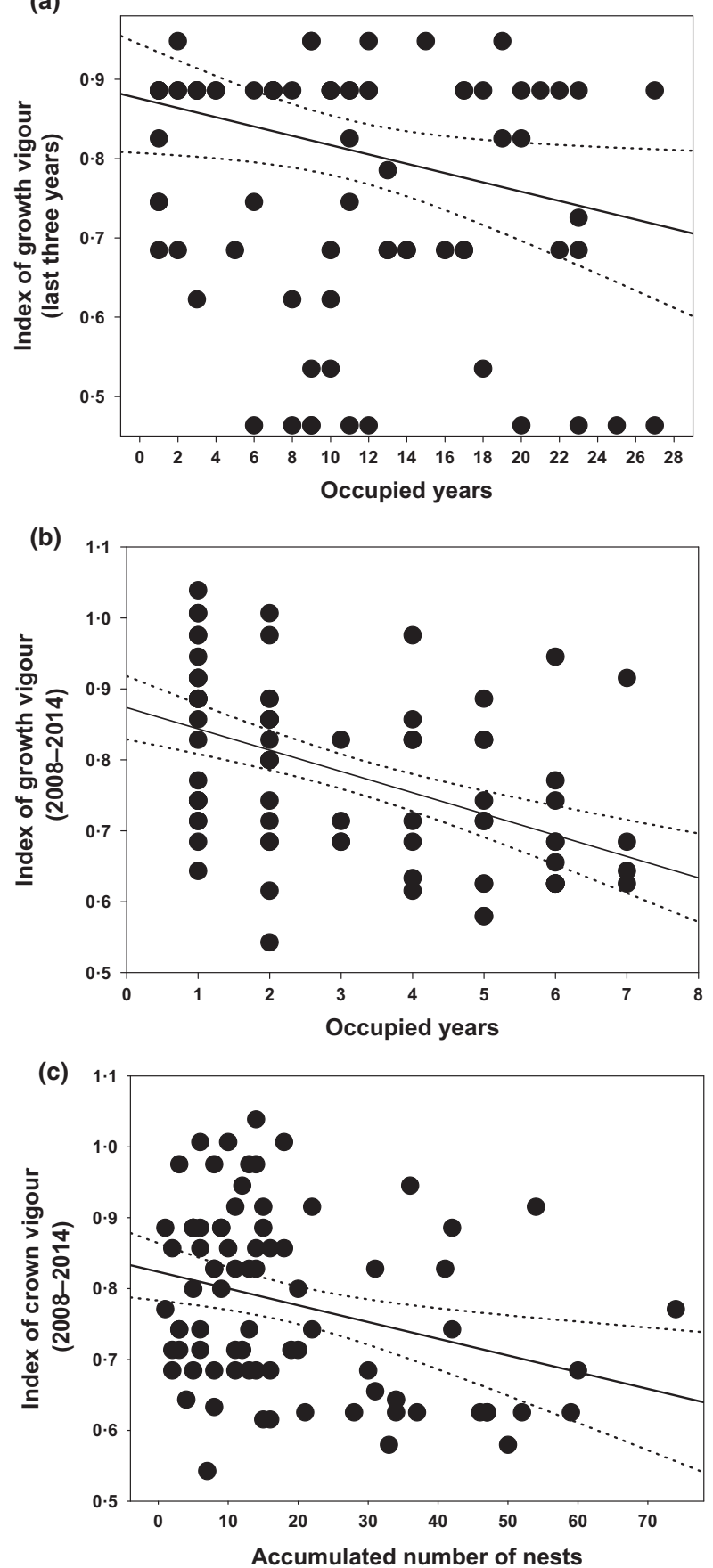

Fig. 4. Significant negative linear relationships and confidence intervals between (a) index of crown vigour (ICV) and total number of years each CO was occupied by the colony $(r=-0 \cdot 242$, $P=0.020 ; R^{2}=0.059$ ), (b) ICV and total number of years each NCO was occupied by the colony during the period 2008-2014 $\left(r=-0.490, P<0.0001, R^{2}=0.2402\right)$, and (c) ICV and accumulated number of nests held by each NCO during the period 2008$2014\left(r=-0.310, P<0.005, R^{2}=0.096\right)$.

occupancy and tree origin $\left(\chi^{2}=0.94\right.$, d.f. $=3, P=0.816$; Fig. 5b). Cox regression did not detect differences in mortality rate between planted and naturally regenerated NCO $\left(\chi^{2}=1.64\right.$, d.f. $\left.=1, P=0 \cdot 200\right)$, though sample size for occupied naturally regenerated oaks was small $(n=5)$. 


\section{(a) Centenarian oaks}

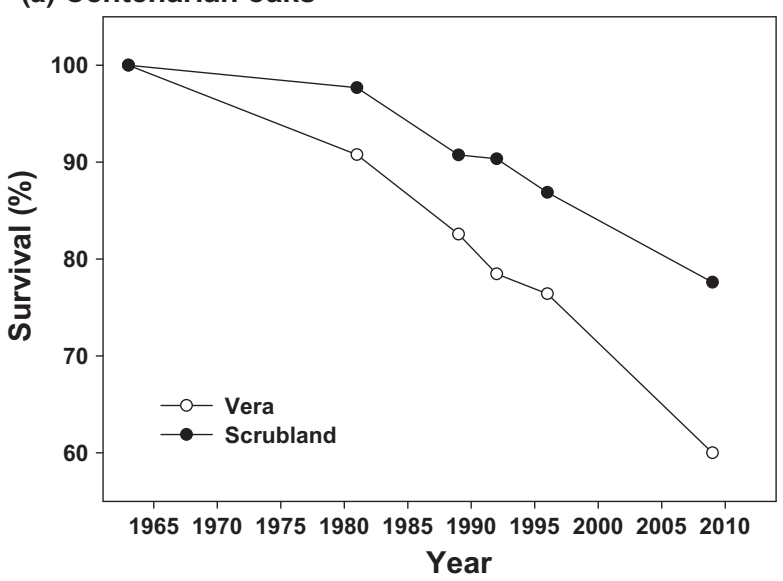

(b) Non-centenarian oaks

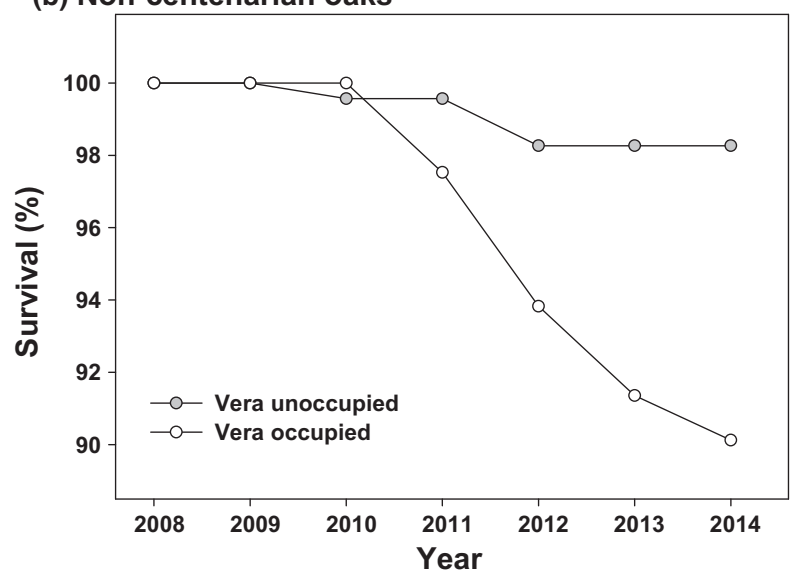

Fig. 5. Cumulative percentages of survival for (a) CO from 1963 to 2009 in the area used (Vera) and not used (Scrubland) by the waterbird colony, and (b) NCO occupied and unoccupied by the colony in the Vera during 2008-2014.

\section{Discussion}

Our long-term investigation revealed marked detrimental effects of a large waterbird colony on the growth, vigour and survival of both centenarian and non-centenarian oaks. Because most colonial waterbird species in Doñana are thriving and expanding their range (Ramo et al. 2013) while the cork oak population is rapidly shrinking, our study questions whether the local presence of such a large colony is compatible with the persistence of this ecologically important oak population. Given the local ecological importance of $\mathrm{CO}$ in Doñana and the global vulnerability of cork oaks to current climate change and other humaninduced factors (Felicísimo et al. 2011), finding a solution to such apparent conflict of conservation interests appears even more urgent.

\section{LONG-TERM DECLINE OF CENTENARIAN OAKS}

Whereas cork oaks thrive best on poor, acidic and nonsaline soils (Serrasolses et al. 2009), colonial waterbirds are known to enrich local topsoils even to a point that may become harmful for plants (García, Marañón \& Clemente 2002; Molina-Montenegro et al. 2013). It is therefore not surprising that the Donana waterbird colony had harmful effects on CO health (García et al. 2011). To what extent such effects translate into lower long-term oak growth and survival, and whether colony-occupied neighbouring conspecifics had a detrimental effect on oak survival, was unknown.

The cessation of oak exploitation in Donana since 1965 (Granados, Martín \& García-Novo 1988; J. Boixo personal communication) likely explains the detected crown condition improvement of CO located outside the Vera. Conversely, tree condition within the Vera, the area used by the colony, worsened during the same period probably because the intense colony activity overrode any potential benefit from the cessation of exploitation. We document not only a marked decrease in growth, health and survival of occupied $\mathrm{CO}$ as compared to unoccupied ones, but also revealed that the more time a tree was occupied the lower crown condition it had. Though oak performance was negatively related to the intensity of colony occupancy, there was also considerable variation in the relationship. Thus, further research to identify the cause of that variation is needed.

Trees occupied by large colonies of nesting birds can lead to tree death within 3-20 years (Belzer \& Lombardi 1989; Baxter \& Fairweather 1994; Ishida 1996). CO in Doñana that died over the last decade were occupied by nests for an average of about 13 years, which suggests a resistance to waterbird colony comparable to that reported elsewhere. After tree death, birds move to other neighbouring trees (Belzer \& Lombardi 1989; Baxter \& Fairweather 1994; Ishida 1996), a pattern also observed in Doñana (J.M. Fedriani, L.V. García, M.E. Sánchez, J. Calderón \& C. Ramo, personal observation). Abandonment of standing dead or dying trees seems related to fragility of their dried out branches, hampering nest permanence. When the forested area is large in relation to the length of tree regeneration cycles and the colony size is moderate, bird colonies are likely to find an alternative site within the area allowing tree regeneration in the abandoned patch (e.g. Parnell et al. 1988). Such resilience seems unlikely for Doñana oaks because of the large colony size in relation to the reduced size of the colony-suitable area, and the low number of living $\mathrm{CO}$, often surrounded by colony-occupied conspecifics. The persistence of this ecologically important oak age class therefore is in conflict with the presence of the large waterbird colony in Doñana.

\section{RESTRICTED NATURAL OAK REGENERATION AND FAILURE OF RESTORATION EFFORTS}

Detrimental effects exerted by the waterbird colony were not limited to large $\mathrm{CO}$, but also markedly affected the health and survival of non-centenarian oaks (see Ayers et al. 2015). The higher colony occupation of planted oaks as compared to naturally regenerated ones seems related to the clumped distribution and proximity to 
marsh of planted oaks (J.M. Fedriani, L.V. García, M.E. Sánchez, J. Calderón \& C. Ramo, unpublished data). It is expected thus that most unoccupied oaks in the Vera, as well as new recruits, will be occupied, harmed and killed within a few decades. The recruitment of new reproductive individuals and the long-term persistence of the oak population are therefore locally threatened.

As documented for other Quercus species (Ishida 1997), the colony likely also lessens oak seedling emergence and growth by means of soil-mediated effects (see GutiérrezHernández et al. 2014) which, together with high herbivore pressure by ungulates and rabbits (Herrera 1995) and local extreme summer droughts (e.g. Fedriani, Zywiec \& Delibes 2012), strongly limit oak seedling establishment and recruitment. Also, by removing large amounts of oak branches and inflorescences for nest construction and by depositing large quantities of faecal material on leaves and flowers, colonial waterbirds seem to lessen oak flowering and seed production (J.M. Fedriani, L.V. García, M.E. Sánchez, J. Calderón \& C. Ramo, personal observation). These hazards should be evaluated in future investigations.

\section{MANAGEMENT IMPLICATIONS AND WIN-WIN STRATEGIES}

Active management directed to reverse the collapse of this oak population is imperative. First, we should ask at what spatial and temporal scales it is possible for both waterbirds and oaks to coexist (Díaz, Tietje \& Barrett 2013), and what strategies can aid coexistence. Given the current critical situation, waterbirds and oaks are unlikely to coexist within the area called Vera, but they certainly can do it at a larger spatial scale, that is the Doñana area. On the other hand, we identify a conflict of interest between stakeholders interested in conservation at Doñana with contrasting sensitiveness towards birds and trees in parks (see McAlpine et al. 2016). We propose the use of a conservation conflict approach (Redpath et al. 2013) to move from a situation where oak and bird conservationists are acting with little compromise towards other interests to a process of conflict resolution where sides accept that this is a shared problem and that trade-offs may be required, if a win-win strategy (sensu Redpath et al. 2013) is not achievable. Such win-win strategies should be based on three main action types: (i) education efforts to convince stakeholders that conservation of both cork oaks and waterbirds is necessary, (ii) the temporal displacement of the colony and (iii) well-planned reforestation campaigns.

Awareness campaigns are a relatively simple and urgent management action needed to convince stakeholders about the necessity to conserve both oaks and waterbirds and, thus, to undertake some management actions. Currently, most social collectives such as environmental activists and some scientists markedly prioritize bird over oak conservation. Such deficient local sensitivity towards plant conservation is illustrated, for example, by the fact that, despite severe $\mathrm{CO}$ decline and the rise of waterbird population numbers, access to Vera continues to be strictly limited during most of the year to prevent disturbance to nesting waterbirds, making the area even more attractive for waterbirds.

Given that there are several other waterbird colonies in Doñana (Ramo et al. 2013), the relocation of the colony located in the $\mathrm{CO}$ to an area of lower conservation value is a 'must do' task. Examples of successful relocations do exist for both small egret colonies (Hafner 1982) and large seabird colonies (Roby et al. 2002). The large size of the Doñana colony likely makes relocation logistically difficult. For example, to attract nesting waterbirds away from $\mathrm{CO}$, some fast-growing riparian species were planted in several instances (e.g. Cadenas \& Solis 1992). Though waterbirds did rapidly colonize planted riparian trees, the colony increased in numbers and thus persisted in nesting on the attractive large $\mathrm{CO}$. To successfully relocate the colony managers should not only provide a suitable alternative nesting place but also scare the waterbirds from $\mathrm{CO}$. In Doñana, there are another 7-8 waterbird colonies which could receive new breeding pairs by planting more trees or erecting artificial platforms (Pearce 2004). Hacking has proved an effective method in these species to attract birds to nest in new sites (Hafner 1982; Parnell et al. 1988). The use of trained birds of prey (Erickson, Marsh \& Salmon 1990) to discourage the nesting of wading birds is an interesting possibility, though it should be considered with caution given the local presence of some protected and sensitive raptor species (e.g. the imperial eagle Aquila adalberti).

Reforestation has been of limited success because planted NCO in the Vera are often rapidly occupied and killed within a few years. Tree plantations should be set away from occupied oaks because they are likely to worsen tree life expectancy. Therefore, planting efforts should be focussed outside the Vera, that is in the rest of the suitable area (scrubland) for cork oaks, where oak juveniles away from the colony are more likely to survive. To preserve the Doñana oak genetic pool, such reforestation should be accomplished using local seeds and seedlings (García et al. 2011). It is therefore urgent to undertake a wide-scale programme of collecting and sowing local acorns to obtain seedlings and saplings for future restoration plans.

The loss of large old trees can create a 'temporary extinction' until the recruitment of new ones replaces them, so management strategies need to span prolonged temporal scales, even centuries (Lindenmayer et al. 2013). Cork oak is a long-lived species that can survive up to 500 years (Ruiz de la Torre 1971) and most of the large oaks at the DBR are older than 250 years (Montoya 1980). As found in other tree species and ecosystems (e.g. Fischer, Stott \& Law 2010; Díaz, Tietje \& Barrett 2013; Lindenmayer et al. 2013), large CO are keystone elements in the Doñana scrubland because they seasonally provide food to ungulates, small mammals and birds as well as shelter and nesting structures for avian and mammalian predators (e.g. García et al. 2011). Thus, the restoration projects aimed at replacing such an ecologically important 
age class of $\mathrm{CO}$ should persist but, given the revealed rapid decline of $\mathrm{CO}$ due to the waterbird colony, urgent and drastic adjustments are needed.

To conclude, our long-term study clearly shows that persistent occupation of centenarian and non-centenarian oaks in Doñana by waterbirds is, at a local scale, incompatible with oak survival and frustrates ongoing restoration efforts. However, waterbirds and oaks can coexist not only at a regional scale, but also within the Doñana area. The historical bird-biased conservation focus in Doñana (Martín-López et al. 2009) should be shifted to a more balanced one that a priori aligns plants and animals into the same priority status (McAlpine et al. 2016). Solving multispecies ecological conflicts requires the collaboration of multiple specialists. In the case of conservation conflicts, stakeholders should enter into a process of conflict resolution (Redpath et al. 2013) and account for the long-term population trends and predictions derived from rigorous, well-informed models (Simberloff 1998; Oro et al. 2009; Schmolke et al. 2010). Conservation priorities and strategies need to be re-evaluated over the years, adopting an adaptive management approach to cope with expected changes resulting from spatial-temporal population dynamics of interacting species.

\section{Acknowledgements}

Managers of DBR provided essential facilities and support. Benjamín Busto and Rocío López helped us in the field. Juan Carlos Solís (d. 1997), Rafa Laffitte, Héctor Garrido and Rubén Rodríguez from the Doñana Monitoring Team, José Boixo, warden of Doñana and Eduardo Aguilera, provided us with valuable information about the oaks and the colony. David Aragonés, from LAST-EBD, drew the map in Fig. 1. Chris Whelan, Danny Hooftman, Ignacio Pérez-Ramos, Juan A. Amat and two anonymous reviewers made numerous useful comments that improved previous drafts. Jennifer Leonard kindly reviewed the English. Consejería de Innovación, Junta de Andalucía/EU-ERDF (BIOGEOBIRD Project P09RMN-4987), provided financial support.

\section{Data accessibility}

The data used in this study have been deposited in the Figshare data repository:

1. Cork oak growth - doi: 10.6084/m9.figshare.3141337 (Fedriani et al. 2016a).

2. $\mathrm{CV}$ of $\mathrm{CO}$ in 1966 and 2010 - doi: $10.6084 / \mathrm{m} 9$. figshare.3141751 (Fedriani et al. 2016b).

3. ICV of planted and natural regenerated NCO - doi: 10.6084/ m9.figshare.3141766 (Fedriani et al. 2016c).

4. ICV and total number of nests of NCO - doi: $10.6084 / \mathrm{m} 9$. figshare.3144724 (Fedriani 2016).

5. ICV and total number of years occupied by the colony of NCO - doi: 10.6084/m9.figshare.3144733 (Fedriani et al. 2016d).

6. ICV and total number of years occupied by the colony of CO - doi: 10.6084/m9.figshare.3144775 (Fedriani et al. 2016e).

\section{References}

Aderman, A.R. \& Hill, E.P. (1995) Locations and numbers of doublecrested cormorants using winter roosts in the Delta Region of Mississippi. Colonial Waterbirds, 18 (Special Publication), 143-151
Aronson, J., Pereira, J.S. \& Pausas, J.G. (eds.) (2009) Cork oak woodlands on the edge: Adaptive Management and Restoration. Island Press, Washington, USA.

Ayers, C.R., Hanson-Dorr, K.C., O'Dell, S., Lovell, C.D., Jones, M.L., Suckow, J.R. \& Dorr, B.S. (2015) Impacts of colonial waterbirds on vegetation and potential restoration of island habitats. Restoration Ecology, 23, 252-260.

Baxter, G.S.\&. \& Fairweather, P.G. (1994) Phosphorus and nitrogen in wetlands with and without egret colonies. Australian Journal of Ecology, 19, 409-416.

Belzer, W.R. \& Lombardi, J.R. (1989) Cattle egret symbiosis and heronry abandonment. Colonial Waterbird, 12, 115-117.

Bolker, B.M., Brooks, M.E., Clark, C.J., Geange, S.W., Poulsen, J.R., Stevens, M.H.H. \& White, J.S.S. (2009) Generalized linear mixed models: a practical guide for ecology and evolution. Trends in Ecology and Evolution, 24, 127-135.

Breuning-Madsen, H., Ehlers-Koch, C., Gregersen, J. \& Løjtnant, C.L. (2010) Influence of perennial colonies of piscivorous birds on soil nutrient contents in a temperate humid climate. Danish Journal of Geography, 110, 25-35.

Cadenas, R. \& Solis, J.C. (1992) Restauración de los alcornoques de la Pajarera del Parque Nacional de Doñana. Recopilación de trabajos del Simposium Mediterráneo sobre regeneración del monte alcornocal (eds E. Jimenez \& P. Marco), pp. 145-148, Instituto de Promoción del Corcho, Badajoz.

Carnicer, J., Coll, M., Ninyerola, M., Pons, X., Sánchez, G. \& Peñuelas, J. (2011) Widespread crown condition decline, food web disruption, and amplified tree mortality with increased climate change-type drought. Proceedings of the National Academy of Sciences, 108, 1474-1478.

Ceballos, G. \& Brown, J.H. (1995) Global patterns of mammalian diversity, endemism, and endangerment. Conservation Biology, 9, 559-568.

Díaz, M., Tietje, W.D. \& Barrett, R.H. (2013) Effects of management on biological diversity and endangered species. Mediterranean Oak Woodland Working Landscapes (eds P. Campos, L. Huntsinger, J.L. Oviedo, P.F. Starrs, M. Díaz, R.B. Standiford \& G. Montero), pp. 213-243. Springer, Netherlands.

Erickson, W.A., Marsh, R.E. \& Salmon, T.P. (1990) A review of falconry as a bird-hazing technique. Proc. 14th Vertebr. Pest Conf (eds L.R. Davis \& R.E. Marsh), pp. 314-316, University of California, Davis, CA.

del Estado, B.O. (2011) Real Decreto 139/2011, de 4 de febrero para el desarrollo del listado de Especies Silvestres en Régimen de protección Especial y del Catálogo Español de Especies Amenazadas. BOE, 46, 20912-22095.

Fedriani, J.M. (2016): NCO ICV x \# of nests. figshare. https://dx.doi.org/ 10.6084/m9.figshare.3144724.v1.

Fedriani, J.M., Zywiec, M. \& Delibes, M. (2012) Thieves or mutualists? Pulp feeders enhance endozoochore local recruitment. Ecology, 93, 575-587.

Fedriani, J.M., Garrote, P.J., Delgado, M.M. \& Penteriani, V. (2015a) Subtle gardeners: inland predators enrich local topsoil and enhance plant growth. PLoS One, 10, 1-14

Fedriani, J.M., Wiegand, T., Calvo, G., Suárez-Esteban, A., Jácome, M., Żywiec, M. et al. (2015b) Unravelling conflicting density and distance dependence of plant reproduction using a spatially explicit framework. Journal of Ecology, 5, 1344-1353.

Fedriani, J.M., García, L.V., Sánchez, M.E., Calderón, J. \& Ramo, C. (2016a): Cork oak growth. figshare. https://dx.doi.org/10.6084/m9.figshare.3141337.v1

Fedriani, J.M., García, L.V., Sánchez, M.E., Calderón, J. \& Ramo, C. (2016b): Index of crown vigour in centenarian oaks. figshare. https://dx. doi.org/10.6084/m9.figshare.3141751.v1.

Fedriani, J.M., García, L.V., Sánchez, M.E., Calderón, J. \& Ramo, C. (2016c): ICV of non-centenarian oaks. figshare. https://dx.doi.org/10.60 84/m9.figshare.3141766.v1

Fedriani, J.M., García, L.V., Sánchez, M.E., Calderón, J. \& Ramo, C. (2016d): NCO ICV x \# years occupied by the colony. figshare. https://dx.doi.org/10.6084/m9.figshare.3144733.v1.

Fedriani, J.M., García, L.V., Sánchez, M.E., Calderón, J. \& Ramo, C. (2016e): ICV and number of years occupied by the colony of CO. figshare. https://dx.doi.org/10.6084/m9.figshare.3144775.v1.

Felicísimo, Á.M., Muñoz, J., Villalba, C.J. \& Mateo, R.G. (2011) Impactos, vulnerabilidad y adaptación al cambio climático de la biodiversidad española. Flora y vegetación. Oficina Española de Cambio Climático, Ministerio de Medio Ambiente y Medio Rural y Marino, Madrid, Spain.

Fischer, J., Stott, J. \& Law, B.S. (2010) The disproportionate value of scattered trees. Biological Conservation, 143, 1564-1567. 
García, L.V., Marañón, T. \& Clemente, L. (2002) Animal influences on soil properties and plant cover in the Chafarinas islands (NW Africa) Man and Soil at the Third Millennium, Vol. 2. (eds J.L. Rubio, R.P.C Morgan, S. Asins \& V. Andreu), pp. 705-712. Geoforma Ediciones, Logroño, Spain.

García, L.V., Ramo, C., Aponte, C., Moreno López, A., Gómez Aparicio, L., Redondo, R. \& Marañón, T. (2011) Protected wading bird species threaten relict centenarian cork oaks in a Mediterranean Biosphere Reserve: a conservation management conflict. Biological Conservation, 144, 764-771.

García-Novo, F. (1979) The ecology of vegetation of the dunes in Doñana National Park (SW Spain). Ecological processes in coastal environments (eds R.L. Jeffreis \& A. Davy), pp. 571-592. Blackwell, Oxford, UK.

García-Novo, F. \& Marín-Cabrera, C. (2005) Doñana: agua y biosfera. UNESCO/Ministerio de MedioAmbiente, Madrid.

Gómez-Aparicio, L., Ibáñez, B., Serrano, M.S., De Vita, P., Ávila, J.M., Pérez-Ramos, I.M. et al. (2012) Spatial patterns of soil pathogens in declining Mediterranean forests: implications for tree species regeneration. New Phytologist, 194, 1014-1024.

Granados, M., Martín, V. \& García-Novo, F. (1988) Long-term vegetation changes on the stabilized dunes of Doñana Nacional Park (SW Spain). Vegetation, 75, 73-80.

Green, A.J. \& Elmberg, J. (2014) Ecosystem services provided by waterbirds. Biological Reviews, 89, 105-122.

Gustavsson, E., Lennartsson, T. \& Emanuelsson, M. (2007) Land use more than 200 years ago explains current grassland plant diversity in a Swedish agricultural landscape. Biological Conservation, 138, 47-59.

Gutiérrez-Hernández, O., García, L.V., Pérez-ramos, I., Ramo, C., Cara, J.S., Gutiérrez, E. et al. (2014) Waterbird detritus impair seedling root growth in a unique centenarian cork oak population: implications for forest regeneration. IOBC-WPRS Bulletin, 101, 47-50.

Hafner, H. (1982) Creation of a breeding site for tree-nesting herons in the Camargue, France. Manual of Active Wetlands and Waterfowl Management (ed. D. Scott), pp. 216-220. IWRB, Slimbridge, UK

Herrera, J. (1995) Acorn predation and seedling production in a lowdensity population of cork oak (Quercus suber L.). Forest Ecology and Management, 76, 197-201

Ishida, A. (1996) Effects of the common cormorant, Phalacrocorax carbo, on evergreen forest in two nest sites at Lake Biwa, Japan. Ecological Research, 11, 193-200.

Ishida, A. (1997) Seed germination and seedling survival in a colony of the common cormorant, Phalacrocorax carbo. Ecological Research, 12, 249256.

Kolb, G.S., Jerling, L., Essenberg, C., Palmborg, C. \& Hambäck, P.A. (2012) The impact of nesting cormorants on plant and arthropod diversity. Ecography, 35, 726-740.

Lindenmayer, D.B., Laurance, W.F., Franklin, J.F., Likens, G.E., Banks, S.C., Blanchard, W. et al. (2013) New policies for old trees: averting a global crisis in a keystone ecological structure. Conservation Letters, 7, 61-69.

Littell, R.C., Stroup, W.W., Milliken, G.A., Wolfinger, R.D. \& Schabenberger, O. (2006) SAS for Mixed Models. SAS institute, Cary, NC.

Martín-López, B., Montes, C., Ramírez, L. \& Benayas, J. (2009) What drives policy decision-making related to species conservation? Biological Conservation, 142(7), 1370-1380

McAlpine, C., Catterall, C.P., Nally, R.M., Lindenmayer, D., Reid, J.L., Holl, K.D. et al. (2016) Integrating plant- and animal-based perspectives for more effective restoration of biodiversity. Frontiers in Ecology and the Environment, 14, 37-45.

Mokhatla, M.M., Measey, G.J., Chimimba, C.T. \& Van Rensburg, B.J (2012) A biogeographical assessment of anthropogenic threats to areas where different frog breeding groups occur in South Africa: implications for anuran conservation. Diversity and Distributions, 18, 470-480.

Molina-Montenegro, M., Torres-Díaz, C., Gallardo-Cerda, J., Leppe, M. \& Gianoli, E. (2013) Seabirds modify El Niño effects on tree growth in a southern Pacific island. Ecology, 94, 2415-2425.

Montoya, J.M. (1980) Los alcornocales (Quercus suber L.). Instituto Nacional de Investigaciones Agrarias, Madrid, Spain

Nogueira, E.M., Nelson, B.W. \& Fearnside, P.M. (2006) Volume and biomass of trees in central Amazonia: influence of irregularly shaped and hollow trunks. Forest Ecology and Management, 227, 14-21

Oro, D., Pérez-Rodríguez, A., Martínez-Vilalta, A., Bertolero, A., Vidald, F. \& Genovart, M. (2009) Interference competition in a threatened seabird community: a paradox for a successful conservation. Biological Conservation, 142, 1830-1835.
Parnell, J.F., Ainley, D.G., Blockpoel, H., Cain, B., Custer, T.W., Dusi, J.L. et al. (1988) Colonial waterbird management in North America. Colonial Waterbirds, 11, 129-345.

Pearce, F. (2004) Bird traffic controller. New Scientist, 184, 48-51.

Pressey, R.L., Whish, G.L., Barrett, T.W. \& Watts, M.E. (2002) Effectiveness of protected areas in north-eastern New South Wales: recent trends in six measures. Biological Conservation, 106, 57-69.

Ramo, C., Aguilera, E., Figuerola, J., Máñez, M. \& Green, A.J. (2013) Long-term population trends of colonial wading birds breeding in Doñana (SW Spain) in relation to environmental and anthropogenic factors. Ardeola, 60, 305-326.

Redpath, S.M., Young, J., Evely, A., Adams, W.M., Sutherland, W.J., Whitehouse, A. et al. (2013) Understanding and managing conservation conflicts. Trends in Ecology \& Evolution, 28, 100-109.

Roby, D.D., Collis, K., Lyons, D.E., Craig, D.P., Adkins, J.Y., Myers, A.M. \& Suryan, R.M. (2002) Effects of colony relocation on diet and productivity of Caspian terns. The Journal of Wildlife Management, 66, 662-673.

Roemer, G.W. \& Wayne, R.K. (2003) Conservation in conflict: the tale of two endangered species. Conservation Biology, 17, 1251-1260.

Root-Bernstein, M., Douglas, L., Smith, A. \& Verissimo, D. (2013) Anthropomorphized species as tools for conservation: utility beyond prosocial, intelligent and suffering species. Biodiversity and Conservation, 22, 1577-1589.

Ruiz de la Torre, J. (1971) Árboles y arbustos de la España peninsular. Escuela Técnica Superior de Ingenieros de Montes. Servicio de publicaciones. Instituto Forestal de Investigaciones y Experiencias, Madrid, Spain.

Schmolke, A., Thorbek, P., DeAngelis, D.L. \& Grimm, V. (2010) Ecological models supporting environmental decision making: a strategy for the future. Trends in Ecology \& Evolution, 25, 479-486.

Serrasolses, I., Pérez-Devesa, M., Vilagrosa, A., Pausas, J.G., Sauras, T., Cortina, J. \& Vallejo, V.R. (2009) Soil properties constraining cork oak distribution. Cork Oak Woodlands on the Edge: Ecology, Adaptive Management and Restoration (eds J. Aronson, J.S. Pereira \& J.G. Pausas), pp. 89-101. Island Press, Washington.

Simberloff, D. (1998) Flagships, umbrellas, and keystones: is single-species management passé in the landscape era? Biological Conservation, 83, $247-257$.

Solís, J.C. (1996) Plan de ordenación del alcornocal de Doñana. Unpublished report, Estación Biológica de Doñana, Spain.

Tablado, Z., Tella, J.L., Sánchez-Zapata, J.A. \& Hiraldo, F. (2010) The paradox of the long-term positive effects of a North American crayfish on a European community of predators. Conservation Biology, 24, 1230-1238.

Telfair, R.C. \& Bister, T.J. (2004) Long-term breeding success of the cattle egret in Texas. Waterbirds, 27, 69-78.

Therneau, T.M. \& Grambsch, P.M. (2000) Modeling Survival Data: Extending the Cox Model. Springer-Verlag, New York.

Tilman, D., May, R.M., Lehman, C.L. \& Nowak, M.A. (1994) Habitat destruction and the extinction debt. Nature, 371, 65-66.

Verissimo, D., MacMillan, D.C. \& Smith, R.J. (2011) Toward a systematic approach for identifying conservation flagships. Conservation Letters, $\mathbf{4}$, $1-8$

Whelan, C.J., Wenny, D.G. \& Marquis, R.J. (2008) Ecosystem services provided by birds. Annals of the New York Academy of Sciences, 1134, $25-60$.

Received 18 January 2016; accepted 4 April 2016

Handling Editor: Danny Hooftman

\section{Supporting Information}

Additional Supporting Information may be found in the online version of this article.

Appendix S1. Neighbouring analyses in Quercus suber at the Doñana National Park (south-west Spain).

Fig. S1. Univariate $(\mathrm{a}-\mathrm{b})$ and bivariate $(\mathrm{c}-\mathrm{d})$ mark correlation functions to detect a potential spatial structure in $\mathrm{CO}$ survival and the number of colony-occupied conspecific neighbours within $50 \mathrm{~m}$. 